\title{
Research on Accounting System of Government and Non-profit Organizations
}

\author{
Jiang Leping \\ (College of Modern Economics \& Management JUFE, Nanchang, 330013)
}

Keywords: Government and non-profit organization accounting; System; Construction; Research

\begin{abstract}
With the further development of the socialism public finance reform and the socialism market economy, due to the lack of a complete government and non-profit organization accounting system, the existing government and non-profit organization accounting systems that rely only heavily on the planned economy are unable to adapt Economic system reform and government management system reform required. The accounting basis of Chinese government and non-profit organizations should be converted from cash to accrual basis. Accounting elements should be based on existing assets, liabilities, net assets, income, and expenditures, and balances should be added. Income and expenditures should be increased in the organization. Importantly, the accounting measurement model is based on historical cost. In order to reliably measure costs, a fixed asset repair fund system or depreciation system should be established. In terms of disclosure of accounting information, it revised the balance sheet format, increased cash flow statement information, attached importance to off-balance-sheet information disclosure, improved financial analysis indicators, and attached great importance to financial analysis. The overall internationalization of budgetary accounting is slow, and the government and non-profit organizations are actively and steadily moving toward accounting internationalization.
\end{abstract}

\section{Introduction}

Government and non-profit organization accounting is an important part of China's budgetary accounting. It is distinctly different from corporate accounting. It has both connections and differences with government and non-profit organization accounting. The study of the basic theoretical issues of the accounting of the Chinese government and non-profit organizations has important theoretical and practical significance. Basic accounting theory is the most basic and important part of accounting theory. Studying this topic takes accounting goals as a logical starting point. The accounting objectives of government and non-profit organizations are based on fiduciary responsibility, which is the unification of fiduciary responsibility and decision-making. The basic assumptions of government and non-profit organization accounting still include accounting entities, continuing operations, accounting periods and currency measurements. However, it is full of new meanings, especially the continuing operations and accounting stages are particularly evident. It is proposed to reform the accounting period of the government and the non-profit organization by using the calendar year and the multi-year system. The establishment of a non-profit organization accounting principle system includes both strategic and tactical aspects, and standardizes accounting work in both macro and micro aspects. Among them, tactical accounting principles include both accounting and supervision. Using Western experience for reference, we build the quality characteristics of the accounting information of our government and non-profit organizations.

\section{Government and Non-profit Organization Accounting}

Engaged in government budget management, government administration, social welfare service activities; not for profit and macro-economic benefits, social benefits; income from taxes, fees, funding, service activities; financial providers do not obtain direct economic benefits Debt exceptions; performance evaluation is based on the benefits, quality, and quantity of management, service; fund system can be implemented, and the types of funds should be set up for close-up 
purposes and purposes. The special method has the following:

(1) Accounting elements (elements of accounting statements) are divided into assets, liabilities, net assets, income, expenses, and balances. The basic accounting equations are: assets $=$ liabilities + net assets, income - expenditure $=$ balances, under the fund system, points For changes in assets, liabilities, fund balances, income, and expenditure fund balances, the basic accounting equations are: Assets - liabilities $=$ fund balances, income - expenditures $=$ fund balance changes;

(2) The accounting confirmation adopts the realization system of receipt and payment, the combination of the accrual accounting system and the realization system of receipt and payment;

(3) Basic accounting statements. In addition to the balance sheet and cash flow statement, there are income and expenditure statements. Under the fund system, there are balance sheet, income, expenditure and fund balance changes, and cash flow statements, all of which are listed in columns according to the type of fund. In addition, the government and its public non-profit organizations also prepare budget comparison tables, which are also compared by fund type under the fund system.

\section{Specific Contents of Accounting Conceptual Framework for Government and Non-Profit Organizations}

The accounting concept framework is also called the theoretical structure. It is an important component of accounting theory, but it is not an accounting principle. Instead, it provides a theoretical basis for formulating, understanding, and applying accounting standards. China's corporate accounting standards are divided into basic criteria and specific criteria. Because there is no theoretical structure of the accounting standards, the concept of the enterprise accounting standards is not uniform and inconsistent between the beginning and the end. Therefore, the construction of the concept framework of China's corporate accounting concept has become increasingly demanding. As the establishment of the accounting conceptual framework between the government and the non-profit organization, we must learn the lessons from the establishment of the enterprise accounting standards and draw lessons from the theoretical structure of foreign government and non-profit organization accounting rules. We must first develop a theoretical framework for the concept of accounting between the government and the non-profit organization. Specific government and nonprofit accounting standards. The government and non-profit organization's accounting concept framework system is constructed under certain accounting conditions based on accounting objectives, accounting assumptions, accounting principles, accounting procedures and methodologies. Specifically include the following aspects:

(1) Accounting objectives of government and non-profit organizations;

(2) Government and non-profit organization accounting assumptions;

(3)Quality characteristics of accounting information of government and non-profit organizations;

(4) Accounting elements of government and non-profit organizations;

(5) The confirmation and measurement of the accounting elements of government and non-profit organizations;

(6) The mode and method of formulating and implementing accounting standards for government and non-profit organizations.

In summary, the special issues to be solved by the accounting concept framework of the government and non-profit organizations are mainly based on the theoretical foundation of public fiduciary responsibility, researching the confirmation and measurement of government special assets and liabilities, and determining the appropriateness of the accrual accounting basis , Form an accounting system, design performance indicators and budget comparison tables that are applicable to government performance evaluation, and overall, identify, measure, record, and report on the resources consumed and achievements made by government performance activities to monitor and evaluate the performance of the job for the government. In addition, whether it is considered that it should maintain its compatibility with the corporate accounting concept framework as much as possible, in order to reduce the cost of the conceptual framework of the government and non-profit organization accounting and the formulation of government and non-profit organization accounting 
standards.

\section{Government and Non-Profit Organization Accounting}

In enterprise accounting, the main body of accounting and the main body of financial reporting are united and basically established according to the ownership boundary. In government and non-profit organization accounting, the two may not be the same. The accounting subjects of government and non-profit organizations are funded under the system of fund accounting. The main body of financial reports is established in accordance with the hierarchical structure of the government. That is, government administrative agencies or administrative units at all levels, and some important funds and projects can be used as the main body of financial reports.

This distinction mainly stems from the special requirements for fund management and control of government activities. Funds are formed separately to achieve a specific purpose or to complete certain activities in accordance with specific regulations, restrictions, or regulations. A set of self-balancing accounts are used to record cash and other financial resources, the balance of related liabilities, and accounting subject with a financial change. The fundamental role of fund accounting, in which funds are the subject of accounting, is to ensure that funds are used exclusively and that financial resources are used for specific purposes for a limited purpose. It is a kind of cooperation and guarantee for budgetary revenue and expenditure accounting. It is a control over the process of resource acquisition and use. This is particularly important in government agencies and organizations that lack the type of corporate constraints. In the West, government and non-profit organization accounting generally adopt fund accounting, forming a fund accounting system composed of government funds, equity funds and trust agency funds. China has not yet adopted fund accounting. Gradually forming and improving the fund accounting system will help the government and non-profit organization's internal control function to play its role effectively.

\section{Government and Non-Profit Accounting Standards}

Under the guidance of the theoretical framework of the conceptual framework for accounting between the government and non-profit organizations, the government and non-profit organization accounting standards regulate the treatment of specific government and non-profit organization accounting businesses. The specific contents of the accounting standards for government and non-profit organizations may include three parts: First, the accounting elements criteria, which mainly provide specific provisions for the confirmation and measurement of accounting elements and information disclosure. Including assets, liabilities, net assets, etc. The second is the accounting statement criteria, which mainly stipulates the content, format and arrangement of items reflected in the report. Including balance sheet criteria, income and expenditure statement criteria, cash flow statement guidelines, and other information disclosure guidelines. The third is the special industry accounting standards. It mainly provides accounting for the accounting of certain special industries. Including budget and decision reporting accounting standards, national accounting standards and donated accounting standards.

\section{Conclusion}

The issue of strengthening the construction of accounting standards for NPOs has become increasingly important. Based on this requirement, this paper selects the basic NPI accounting standards as the research object, and discusses some basic issues in order to help establish the government and non-profit organization accounting in our country. Guidelines. The establishment of a criterion must be forward-looking so that it can be applied for a certain period of time in the future. It also needs to take into account practicality and practicality so that it can solve existing problems. Based on the comparative analysis of relevant documents at home and abroad, combined with the actual situation of the Chinese government and non-profit organizations, this paper builds a new basic accounting standard for government and non-profit organizations on the basis of existing 
accounting standards for government and non-profit organizations. frame. Clearly follow the modified accrual accounting system in non-profit organizations, and propose new insights into the five elements of non-profit organization accounting; discuss the details of the formats of statements in financial accounting reports, and outlinethe basic framework of non-profit organization accounting.

Fund project:Jiangxi provincial university humanities and social sciences research project(No.JC17207)

\section{References}

[1] Saemann G. An Examination of Comment Letters Filed in the U.S. Financial Accounting Standard - Setting Process by Institutional Interest Groups[J]. Abacus, 2014, 35(1):1-28.

[2] Balakrishnan K, Cohen D A. Competition and Financial Accounting Misreporting[J]. Social Science Electronic Publishing, 2014, 115(Pt11):2433-2442.

[3] Uyar A, Güngörmüş A H. Factors associated with student performance in financial accounting course[J]. European Journal of Economic \& Political Studies, 2016, 4(2):139-154.

[4] Brimble M, Hodgson A. On the intertemporal value relevance of conventional financial accounting in Australia[J]. Accounting \& Finance, 2014, 47(4):599-622.

[5] Lovell H. Climate change, markets and standards: the case of financial accounting[J]. Economy \& Society, 2014, 43(2):260-284.

[6] Mylonidis N, Kelnikola I. Merging activity in the Greek banking system: a Financial Accounting Perspective[J]. South-Eastern Europe Journal of Economics, 2015, 3(1).

[7] Callen J L. A selective critical review of financial accounting research $i[\mathrm{~J}]$. Critical Perspectives on Accounting, 2015, 26:157-167.

[8 ]Foster D A. FRA: Teaching Financial Accounting with a Goal - Based Scenario[J]. Intelligent Systems in Accounting Finance \& Management, 2015, 4(3):173-189.

[9 ] Scott W R. Commentary: An International Comparison and Evaluation of Financial Accounting Concepts Statements*[J]. Accounting Perspectives, 2014, 1(2):163-184.

[10] Glover J C. Have Academic Accountants and Financial Accounting Standard Setters Traded Places?[J]. Social Science Electronic Publishing, 2014, 4(1):17-26.

[11] Carlon S, Mcalpinemladenovic R, Palm C, et al. Financial Accounting: Reporting, Analysis and Decision Making 5th Edition[J]. Plastics News, 2015.

[12] Stockenstrand, AnnaKarin, Nilsson, et al. Financial Accounting and Management Control[J]. Contributions to Management Science, 2015. 